\title{
Differential Response of Subalpine Meadow Vegetation to Snow Augmentation
}

DENNIS H. KNIGHT, SAM W. WEAVER, C. RICHARD STARR, AND WILLIAM H. ROMME

\begin{abstract}
Experimental results from two subalpine meadows in Wyoming suggest that prolonged snow cover due to winter cloud seeding could increase the productivity of dry meadows while causing a decline in the productivity of mesic meadows. Shifts in species composition may also occur. Though statistically significant, the observed effects were subtle and would be expected primarily in areas where larger snow drifts could develop.
\end{abstract}

Snowfall in the Rocky Mountains is important not only as a major supply of water for the adjacent semiarid plains, but also as a factor regulating plant growth on mountain rangelands. Numerous studies have demonstrated how plant growth and species composition vary along natural gradients of snow cover duration (Gjaerevoll 1956; Billings and Bliss 1959; Holway and Ward 1963; Billings 1969; Gorchakovskii and Shiyatov 1971; Canaday and Fonda 1974; Weaver 1974; Knight, Rogers and Kyte 1977), and several experimental studies have shown how the artificial accumulation of snow with fences can cause changes in alpine tundra and mountain meadow vegetation (Webber et al. 1976; Weaver and Collins 1977). These studies were stimulated in part by an interest in the potential on-site ecological effects of snowpack augmentation by winter cloud seeding and have shown how prolonged snow cover may cause a reduction in plant productivity, apparently by reducing growing season length. The effect is slight if the duration of snow cover

Authors are professor and students or former students in the Department of Botany, University of Wyoming, Laramie 8207I.

This work was supported by Contract No. 14-06-D-7198 with the Office of Atmospheric Resources Management, Bureau of Reclamation, U.S. Department of Interior. The authors gratefully acknowledge the field assistance of Russ Campbell. Tim Fahey. Clay Kyte, Marvin Maxell, and Brant Rogers. Dr. Lyman McDonald provided assistance with the statistical analyses, and $\mathrm{Dr}$. T.W. Weaver made helpful suggestions on the manuscript.

Manuscript received August 28, 1978. is increased by less than a week, but may be considerable where snow persists longer.

Our study was motivated similarly by the prospect of winter cloud seeding in the Medicine Bow Mountains of southeastern Wyoming. In addition to studying the effect of snow duration on forest understory vegetation (Knight et al. 1977), we initiated an artificial snow accumulation experiment in two subalpine meadows, one dry and one mesic. For 5 years plots were subjected to a snow cover duration 7-9 days longer than paired control plots. No previous snow-duration experiments had been done in the types of meadow which we studied (a dry SibbaldiaPolytrichum meadow and a mesic Carex-Poa-Plantago meadow).

\section{Methods}

The study was conducted in Headquarters Park on the west side of the Medicine Bow Mountains. The two meadows were located within 200 meters of U.S. Highway 130 , the dry meadow being at an elevation of $3,109 \mathrm{~m}$ and the mesic meadow at $3,054 \mathrm{~m}$. Starr (1974) found soil moisture to be one of the most important factors differentiating the meadows of this Park, dry meadows developing a moisture deficit by early July, mesic meadows having moist soil until late July, and wet meadows remaining moist throughout the growing season. The two sites selected for our experiment are typical of the dry and mesic meadows in that area.

A randomized complete block design was used for the experiment, with 5 pairs of plots (each $1.5 \mathrm{~m}^{2}$ ) in each meadow. The 5 pairs were located in a homogeneous area of about $12 \times 25 \mathrm{~m}$, the plots of each pair appearing visually to be very similar in species composition. One plot of each pair was randomly selected to receive the snow treatment, which consisted of shovelling by hand of a sufficient amount of snow for the plots to remain snow-covered for 7-9 days longer than the 
control plots. Although it is generally assumed that cloud seeding would prolong snow cover only 3-5 days (Leaf 1971; Frank 1973), drifted snow that results from seeding could persist for a longer period (Weaver and Collins 1977). We chose a treatment which appeared to be the maximum possible that could occur as a result of winter cloud seeding.

The snow treatment was applied each spring from 1973 to 1977 . In addition to retarding plant growth for a 7-9 day period, the treatment also increased the water and nutrients (in the snow) available to that plot by several hundred percent. This aspect of the treatment will be discussed.

In addition to noting the snow-free date for each plot during each year of the experiment, seasonal patterns of soil moisture and soil temperature in the primary rooting zone $(10-25 \mathrm{~cm})$ were determined for each plot in 1977, the fifth and last year of the experiment. Soil moisture was measured gravimetrically and temperature was measured with a soil thermometer. Rooting zone soil water holding capacity was estimated in each meadow by multiplying percent soil moisture 24 hours after saturation in the field and bulk density measured with the pit method (Black 1965).

The 5-ycar treatment effect was determined by analysis of variance on current-year, season's end, above-ground biomass data collected on August 11-12, 1977, from $0.5 \times 1.0 \mathrm{~m}$ plots located in the approximate center of the $1.5 \mathrm{~m}^{2}$ treatment and control plots. Aboveground growth appeared to have been completed by that time in all plots. All vegetation was clipped to the soil surface and then frozen until species separation could be done in the lab. A subsampling procedure was used for the two dominant species of the dry meadow, Sibbaldia procumbens and Polytrichum juniperinum. Otherwise, the entire samples were sorted by species, with species nomenclature following that of Dorn (1977). All samples were dried at $55^{\circ} \mathrm{C}$ for 48 hours after species separation, with dry weights being determined to $0.01 \mathrm{~g}$.

\section{Results}

Figure 1 illustrates the degree to which the treatment prolonged snow cover, compared to the control plots, and the annual variation in snowfree date during the 5 -year period. The early melt of 1977 can be attributed to the light snowfall which occurred throughout the central Rocky Mountains during the 1976-77 winter. Despite below-average snowfall, the soils of both meadows were filled to field capacity in the rooting zone (mesic meadow $97 \%$, dry meadow $52 \%$ ).

The vegetation of the dry and mesic meadows responded

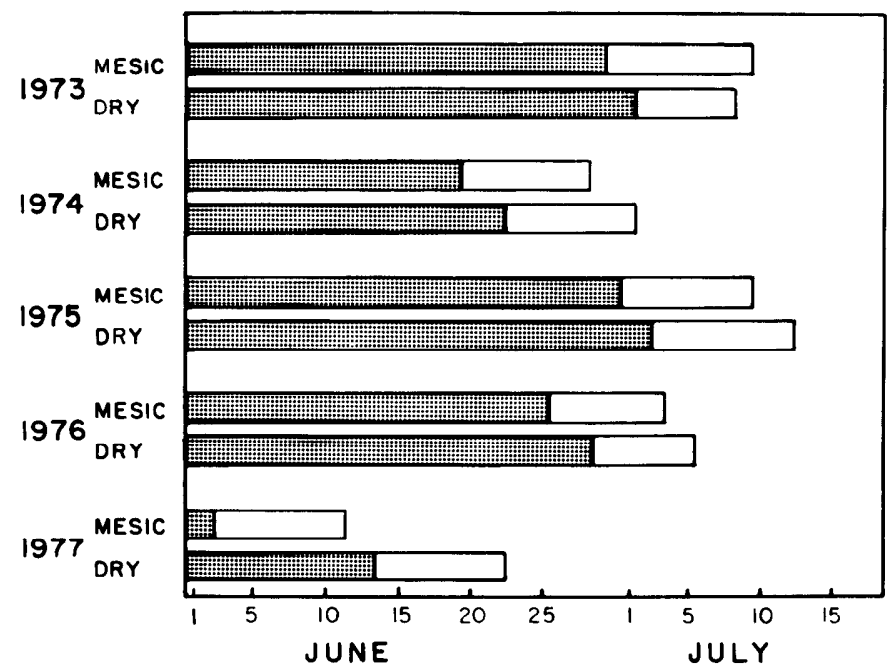

Fig. 1. Snow cover duration on the control (stippled) and treatment plots of the mesic and dry meadows during the 5 -year study period. In 1978 the meadows nere snow-covered until July 13, due to the heavy winter snowfall.
Table 1. Dry weight biomass $\left(\mathrm{g} / \mathrm{m}^{2}\right)$ of all species found on the control and snow-treatment plots at the dry meadow in Headquarters Park, Medicine Bow Mountains, Wyoming. The data were collected after applying the snow treatment for five consecutive years.

\begin{tabular}{|c|c|c|c|}
\hline Species & $\begin{array}{c}\text { Control } \\
\bar{X}\end{array}$ & $\begin{array}{c}\text { Treatment } \\
\qquad \bar{X}\end{array}$ & $\bar{F}$ \\
\hline Sibbaldia procumbens & 42.0 & 62.0 & $16.21(\mathrm{p}<.05)$ \\
\hline Polytrichum juniperinum & 9.8 & 9.9 & 0.0001 \\
\hline Carex hoodii & 4.1 & 12.0 & 5.25 \\
\hline Achillea lanulosa & 2.3 & 3.0 & 2.00 \\
\hline Polygonum bistortoides & 2.1 & 3.6 & 2.32 \\
\hline Juncus drummondii & 1.6 & 2.5 & 1.99 \\
\hline Viola adunca & 1.4 & 2.8 & 0.97 \\
\hline Agrostis thurberiana & 1.2 & 0.9 & 1.05 \\
\hline Arenaria rubella & 1.0 & 1.9 & $10.41(\mathrm{p}<.10)$ \\
\hline Potentilla diversifolia & 0.7 & 1.3 & 0.56 \\
\hline Luzula spicata & 0.5 & 0.2 & \\
\hline Erigeron sp. & 0.4 & 0.1 & \\
\hline Poa reflexa & 0.2 & 0.1 & \\
\hline Gentiana amorilla & 0.2 & 0.2 & \\
\hline Phleum alpinum & 0.1 & 0.2 & \\
\hline Thlaspi montanum & 0.1 & 0.5 & \\
\hline Antennaria sp. & 0.1 & & \\
\hline Hieracium gracile & 0.1 & 0.2 & \\
\hline Scuttelaria brittanii & 0.4 & & \\
\hline Lewisia pygmaea & 0.1 & 0.1 & \\
\hline Other species & 1.7 & 1.6 & \\
\hline Total green biomass & 67.8 & 101.7 & $17.80(\mathrm{p}<.05)$ \\
\hline
\end{tabular}

differently to the snow treatment. The mean total dry weight $\left(\mathrm{g} / \mathrm{m}^{2}\right)$ of treated dry meadow plots was $50 \%$ higher $(P>95 \%)$ than the control plots (Table 1), whereas in the mesic meadow the treated plots had $44 \%$ less $(p>95 \%)$ biomass than the control plots (Table 2). Dry meadow species having a pronounced increase with prolonged snow cover were Sibbaldia procumbens $(+47 \%)$, Arenaria rubella $(+90 \%)$, and Carex

Table 2. Dry weight biomass $\left(\mathrm{g} / \mathrm{m}^{2}\right)$ of all species found on the control and snow-treatment plots at the mesic meadow in Headquarters Park, Medicine Bow Mountains, Wyoming. The data were collected after applying the snow treatment for five consecutive years.

\begin{tabular}{|c|c|c|c|}
\hline & Control & Treatment & \\
\hline Species & $\bar{X}$ & $\bar{X}$ & $\bar{F}$ \\
\hline Carex hoodii & 55.1 & 38.8 & 2.22 \\
\hline Poa reflexa & 53.4 & 10.4 & $10.97(\mathrm{p}<.10)$ \\
\hline Plantago tweedii & 17.0 & 23.2 & 0.38 \\
\hline Trisetum spicatum & 14.0 & 1.5 & 0.88 \\
\hline Erigeron sp. ${ }^{1}$ & 10.7 & 7.3 & 1.18 \\
\hline Juncus drummondii & 9.0 & 4.7 & 0.79 \\
\hline Senecio dimorphophyllus & 7.2 & 6.1 & 0.06 \\
\hline Ranunculus alismaefolius & 6.1 & 7.2 & 1.14 \\
\hline Veronica wormskjoldii & 5.8 & 1.1 & 2.27 \\
\hline Phleum alpinum & 2.6 & 1.0 & 1.24 \\
\hline Potentilla diversifolia & 2.4 & 7.9 & 2.39 \\
\hline Thlaspi montanum & 1.8 & 7.3 & 4.44 \\
\hline Achillea lanulosa & 1.6 & 5.6 & 0.71 \\
\hline Poa alpina & 1.4 & 0.5 & 0.40 \\
\hline Epilobium halleanum & 0.8 & 0.1 & \\
\hline Gentiana amarilla & 0.7 & & \\
\hline Spergularia rubia & 0.6 & 1.8 & \\
\hline Rorippa curvipes & 0.6 & 0.6 & \\
\hline Polygonum bistortoides & 0.4 & 1.4 & \\
\hline Viola sp. & 0.4 & 0.4 & \\
\hline Scuttelaria brittonii & 0.3 & & \\
\hline Sibbaldia procumbens & 0.04 & & \\
\hline Other species & 3.8 & 4.2 & \\
\hline Total green biomass & 191.6 & 132.7 & $17.53(\mathrm{p}<.10)$ \\
\hline
\end{tabular}

'Includes Erigeron peregrimus and another unidentified species of Erigerom. 
hoodii ( $+195 \%$, not significant); none of the dry meadow species declined significantly. In the mesic meadow decreases in biomass were noted for Carex hoodii ( $-29 \%$, not significant) and Poa reflexa $(-80 \%)$. Two mesic meadow species appeared to increase with the 5-year snow treatment (Thlaspi montanum $(+305 \%)$ and Potentilla diversifolia $(+229 \%)$, though the differences are not significant at the $90 \%$ confidence level.

Although the treatment plot soils remained saturated and cold (unfrozen, $0.5^{\circ} \mathrm{C}$ ) for a longer period while snow-covered, equilibration with the control plots occurred within 12 days after becoming snow-free on the dry meadow and within 21 days on the mesic meadow. The dry meadow soil $(0-20 \mathrm{~cm})$ was saturated at $52 \%$ dry weight, the mesic meadow at $97 \%$; but by July 7,1977 , the soil moisture in the two meadows was at $25 \%$ and $40 \%$, respectively.

\section{Discussion}

Our results add a further dimension to the ongoing impact analysis of snowpack augmentation by cloud seeding, primarily in showing that different types of meadows may respond differently to increased snowfall. In this discussion we suggest an explanation for our results and evaluate their relevance to actual cloud seeding.

In addition to delaying growth in the spring and thereby shortening the growing season, our snow treatment also increased the water and nutrients entering the soil and probably facilitated litter decomposition (Webber et al. 1976) and mineralization. Despite the potential benefits of additional water and nutrients (atmospheric nutrient input), the snow treatment caused a reduction in season's end biomass at the mesic meadow. It seems probable that growing season length is the limiting factor on our mesic (Carex-Poa-Plantago) meadow, a conclusion reached also by Weaver and Collins (1977) for subalpine Festuca idahoensis meadows in Montana and by Webber et al. (1976) for Colorado alpine tundra. Indeed, the northern and central Rocky Mountains are characterized by a short, cool growing season that is often terminated by water stress due to a lack of effective summer precipitation. Adding water late in the summer might lengthen the growing season, but the addition of water as snow in the spring only shortens it due to prolonged snow cover, at least on some meadows. The soil is normally saturated at the time of snowmelt (Starr 1974) and, therefore, the additional water from snow would not be important for plant growth.

Although a shortened growing season appears to be the limiting factor imposed by our treatment on the mesic meadow, nutrients also could become limiting after a period of abnormal leaching. Some nutrients are added with the snow (Knight, unpublished data), but we do not know if that quantity balances the amount that could be leached by the additional water. The normal snowpack is more than adequate to leach these meadows, however, and for this reason we tend to place more credence in the shortened growing season hypothesis. Additional data on nutrient loss are needed to be confident.

A different explanation is obviously required for the dry meadow, where biomass increased even though dormancy was prolonged by the snow treatment. Here too the soil was saturated in the rooting zone by melting snow (even during the low snowpack year of 1976-77), suggesting that additional water would not be effective. However, the additional water may have wet the soil to a greater depth than normal, thereby providing, via the deeper plant roots or capillary movement from below, a greater supply of water for plant growth.
Unfortunately, we monitored soil moisture only in the major rooting zone $(10-25 \mathrm{~cm})$. Additional water accessible by deeper roots could prolong the growing season into the summer, thereby allowing the increased productivity observed on the treatment plots. The additional nutrients contributed by the increased snowpack could have further stimulated plant growth on those plots, an effect which could result from cloud seeding as well.

It is possible that the positive effect of increased snowpack on the dry meadow was observed only because of the dry conditions during the 1976-77 winter. Although the soil in the major rooting zone was saturated, it may not have been wetted as deeply as following a normal amount of snowmelt. Thus, the snow treatment could have allowed a normal level of productivity. the control plots being below normal. The effect of the dry winter was not observed at the mesic meadow, but here, unlike the dry meadow, there is considerable surface runoff from upslope. The mesic meadow receives water from a larger area, whereas the dry meadow receives only water that falls on the site.

Therefore, we cannot prove that the increased biomass observed on the dry meadow treatment plots was the result of a single low-snowfall year or the cumulative effect of 5 years of added snow. In either case, however, the dry meadow responded differently than the mesic meadow, a conclusion relevant to evaluating the ecological impact of cloud seeding.

Snowbank experiments do not exactly duplicate the effect of a cloud seeding operation. For example, the potentially toxic seeding agent, silver iodide, is not used. Also, in order to maintain snow cover for 7-9 days on our treatment plots it was necessary to increase the snow by several hundred percent (due to the island or clothesline drying effect). Cloud seeding probably will increase snowfall by only $15-20 \%$, which would normally delay plant growth for no more than 3-5 days on sites where drifting does not occur (Leaf 1971; Haeffner and Leaf (1973). Our results, therefore, show the most extreme changes expected on level sites and the probable responses for sites where larger snow drifts could develop if more snowfall occurred (probably a small proportion of the landscape).

From another perspective, our results suggest that drastic, undesirable changes in mountain meadow vegetation are now likely to occur as a result of snowpack augmentation. The changes that do occur will be variable from one site to another and difficult to detect. Slight shifts in species composition may occur. but with no serious consequences of which we are aware. The objective of winter cloud seeding, however, is to add more water to western watersheds, a potential benefit for many people on the adjacent semiarid plains. Users of this additional water could become dependent on it. After many years of additional water flowing through soils, effects may become apparent that are difficult to predict from a short-term experiment.

\section{Literature Cited}

Billings, W.D. 1969. Vegetational pattern near alpine timberline as affected by fire-snowdrift interactions. Vegetatio 19:192-207.

Billings, W.D., and L.C. Bliss. 1959. An alpine snowbank environment and its effect on vegetation, plant development and productivity. Ecology 40:388-397.

Black, C.A. (ed). 1965. Methods of soil analysis. Amer. Soc. of Agron. Series No. 9. 1572 p.

Canaday, B.B., and R.W. Fonda. 1974. The influence of subalpine snowbanks on vegetation pattern, production, and phenology. Bull. Torrey Bot. Club 101:340-350.

Dorn, R.D. 1977. Manual of the Vascular Plants of Wyoming. Garland Publishing, Inc., New York. 1,498 p (2 Vols.). 
Frank, E. 1973. Snow amount in relation to streamflow and herbage production in western Colorado. J. Range Manage. 26:32-34.

Gjaerevoll, O. 1956. The Plant Communities of the Scandinavian Alpine Snow Beds. Trondheim I Kommisjon Hos. F. Burns Bokhandel. 405 p. Gorchakovskii, P.L., and S.G. Shiyatov. 1971. Phytoindication of snow cover and snow avalanches in the high mountains. Soviet J. Ecol. 2:13-22 (English transl.).

Haeffner, A.D., and C.F. Leaf. 1973. Aerial snow cover observations in the central Rockies, Colorado. U.S. Dep. Agr. Forest Serv., General Tech. Rep. RM-5. 15 p.

Holway, J.G., and R.T. Ward. 1963. Snow and meltwater effects in an area of Colorado alpine. Amcr. Midl. Natur. 69:189-197.

Knight, D.H., B.S. Rogers, and C.R. Kyte. 1977. Understory plant growth in relation to snow duration in Wyoming subalpine forest. Bull. Torrey. Bot. Club 104:314-319.
Leaf, C.F. 1971. Progress report for the period January 1, 1971 to June 30, 1971 to the Division of Atmospheric Water Resources Management, Bureau of Reclamation, IJ.S. Dep. Interior (Contract 14-06-D-5496), Denver, Colo.

Starr, C.R. 1974. Subalpine meadow vegetation in relation to environment at Headquarters Park, Medicine Bow Mountains, Wyoming. MS Thesis, Dep. Botany, Univ. of Wyo. 94 p.

Weaver, T. 1974. Ecological effects of weather modification: Effect of late snowmelt on Festuca idahoensis Elmer meadows. Amer. Midl. Natur. 92:346-356.

Weaver, T., and D. Collins. 1977. Possible effects of weather modification (increased snowpack) on Festuca idahoensis meadows. J. Range Manage. 30:451-456.

Webber, P.J., J.C. Emerick, D.C. Ebert May, and Vera komarkova. 1976. The impact of increased snowfall on alpine vegetation, p. 201-264. In: H.W. Steinhoff and Jack D. Ives (eds), Ecological Impacts of Snowpack Augmentation on the San Juan Mountains, Colorado. Final Rep., San Juan Ecology Project, Colorado State Univ. Publ., Fort Collins, 489 